\title{
THE EXPERIENCES OF MOTHERS WHO LOST A BABY DURING PREGNANCY
}

\author{
Dr L Modiba \\ D Cur (RAU) Midwifery \& Neonatology \\ D Cur Student, University of Johannesburg

\section{Prof AGW Nolte} \\ $\mathrm{PhD}$ \\ Professor, Department of Nursing Science, University of Johannesburg \\ Corresponding author: agwnolte@uj.ac.za
}

Keywords: loss of baby during pregnancy; miscarriage; neonatal death; stillbirths; experiences

\begin{abstract}
The purpose of this study was to explore and describe the experiences of mothers who lost a baby during pregnancy and care given by doctors and midwives during this period. To realise this goal the researcher followed a qualitative, exploratory, descriptive and contextual approach. Data were collected by using in-depth unstructured interviews. The interviews were taped and transcribed verbatim. Data were analysed through open coding. Data were collected until saturation had occurred. All mothers who were interviewed described their experiences of the loss of a baby during pregnancy. Some shared the same experiences and others did not. In the findings of this research, it became clear that mothers with the loss of a baby during pregnancy had experienced hardships and difficult times during this period. They expressed the wish that people acknowledge their loss, be considerate, sensitive, and give them a listening ear and emotional support. On the other hand, mothers identified the inability of health workers to give them the appropriate support.
\end{abstract}

\section{OPSOMMING}

Die doel van die studie was om die ervaring van moeders met betrekking tot die dood van 'n baba tydens swangerskap te verken en te beskryf, asook die versorging wat hulle van vroedvroue en dokters gedurende die periode ontvang het. Die doel is bereik deur ' $n$ kwalitatiewe, verkennende, beskrywende en kontekstuele ontwerp te volg. Data is ingesamel deur middel van in-diepte onderhoude. Die onderhoude is op band opgeneem en verbatim getranskribeer. Data is deur middel van oop kodering geanaliseer. Data is versamel totdat versadiging bereik is. Al die moeders met wie onderhoude gevoer is het hulle ervarings van die verlies tydens swangerskap beskryf. Sommige het dieselfde ervarings gehad en ander nie. Dit was duidelik in die bevindinge van die navorsing dat moeders wat die verlies tydens swangerskap beleef het, moeilike tye beleef het, en daarom gewens het dat mense begrip vir hulle verlies sou hê en ook konsidererend en sensitief sou wees, na hulle sou luister en aan hulle emosionele ondersteuning sou gee. Hierteenoor het moeders die onvermoë van gesondheidswerkers om die ondersteuning te gee geidentifiseer. 


\section{INTRODUCTION AND BACKGROUND}

The loss of a baby during pregnancy can take numerous forms, given individual circumstances. These could be a miscarriage, an ectopic pregnancy, or a stillbirth, which means loss of an embryo or a fetus. The loss of a baby during pregnancy not only involves the catastrophe of a baby's death, but also shatters parents' dreams, plans and hopes. "Grief or mourning", or bereavement, means to be robbed of something valued, because that something, or someone, has been unfairly taken away, it is understandable that the experience of being bereaved is one of strong, overwhelming and sometimes even violent reactions (Baker \& Nackerud, 1999:1). The loss of a baby during pregnancy holds great significance for the parents, the loss of an adult is the loss of the past, and the loss of the baby is the loss of the future. A baby can represent hope for the future, hope of a better life, and hope of greater opportunities. A baby can represent the potential for fulfilling the dreams, a way of starting over, another chance to alter the course of a lifetime. A baby can embody dreams and fantasies. The child can become a part of the parent's identity, and that part of the identity is lost. It is no surprise that the loss of a baby during pregnancy often results in increased anxiety in subsequent pregnancy and feelings of guilt. And this period is oftentimes a period of crisis.

One must be careful, however, to avoid making assumptions about the meaning of the loss of a baby during pregnancy to a particular woman. It is difficult, if not impossible, for anybody else to understand the significance of a pregnancy or a baby to another person. This is because the loss of a baby during pregnancy carries with it a vast range of profoundly deep feelings, which include unspoken hopes and expectations based on personal as well as cultural values. Attempts have been made to compare the severity of grief following loss at different stages, perhaps to demonstrate that certain women deserve more sympathy or care. A study investigating this point, however, showed no significant differences in the grief response between mothers losing a baby by miscarriage, stillbirth or neonatal death (Frazer \& Cooper, 2003:696).

Those who have lost newborns or who have experienced stillbirths have found that people do not recognise the loss as being as tragic as the loss of an older child.
The death of an infant is often considered "an unfortunate occurrence", and one that can easily be rectified by the birth of another child. Often, no one but immediate family members see the baby. Because of this, to most people, the baby did not exist as a "real person" and they cannot begin to be aware of the love, the hopes and the future that were lost with that child (Mander, 1988:1).

According to Condon (1986:987), there are repeated findings in the literature that approximately one third of parents bereaved by stillbirth perceive the obstetric team as failing to provide adequate support or information in both the short and longer terms. These parents may be at greater risk of subsequent psychiatric illness.

\section{PROBLEM STATEMENT}

Although the general topic of death and dying is receiving increasing attention by the medical community, the problem is that little is known about the impact that the loss of a baby during pregnancy has on the lives of those experiencing it. What happens to these people after the woman is discharged from the hospital? How do parents as individuals react to their loss? What happens to a couple's relationship with each other as a result of their baby's death? (Kennel \& Klaus, 1982:267).

In Kennel and Klaus (1982:264), it is stated that there is a wide range of reactions of people in response to the loss of a baby during pregnancy. Its potential effects can alter the lives of those who experience it. The grief each person feels is a unique part of them. Therefore, no one else can completely understand another's pain. Thus, it is important to describe and explore the experiences of every mother who experiences the loss of a baby during pregnancy.

In practice the researcher experienced that there are many complaints from bereaved mothers about the lack of support given to them during their grieving process. The mothers verbalise that all the doctors and midwives seem to care about is that the baby has been delivered, after which they apparently do not care about the emotional trauma the mother is undergoing. The strongest reactions probably occur when there are comments suggesting that the family should forget about the loss and get on with their lives or get on with 
another pregnancy. It may be even suggested that the baby was small and therefore their loss should not be as great as it would have been if the baby had lived longer (Kennel \& Klaus, 1982:267).

From the above-mentioned problem statement the following questions arose:

- How did the mothers experience the loss of a baby during pregnancy?

- How did the mothers experience care given by midwives and doctors during the loss of a baby during pregnancy?

\section{PURPOSE OF THE RESEARCH}

The overall objective of this research was to describe the experiences of mothers with the loss of a baby during pregnancy and the professional care they received during this period in the maternity unit of a public hospital in Gauteng Province, South Africa.

\section{DEFINITIONS OF TERMS}

Concepts used in this study are defined as follows:

The loss of a baby during pregnancy: This is when a mother looses an embryo/fetus during pregnancy due to a miscarriage, an ectopic pregnancy, or a stillbirth (Woods \& Esposito, 1987:120).

Bereavement: Bereavement is defined as the entire process precipitated by loss through death. In this research the bereaved are mothers who have lost a pregnancy (Woods \& Esposito, 1987:5).

Support: In this study, support is that function that prevents or reduces stress in a mother with the loss of a baby during pregnancy. Supporting her makes her feel accepted and respected. She is reassured that she is cared for and is allowed to communicate freely and share her experiences and feelings. The support should be given initially by health workers, and later in co-operation with family and other community members, for example, the church.

Miscarriage: Spontaneous loss of pregnancy before viability (Frazer \& Cooper, 2003:1034).

Experience: It involves gaining knowledge by being personally involved in an event, a situation or a circumstance (Burns \& Grove, 2003:15).

\section{RESEARCH DESIGN AND METHOD}

In this research, a qualitative research design, which is exploratory, descriptive and contextual in nature (Mouton, 1996:169; Mouton \& Marais, 1990:45), was used.

Understanding the meaning of a phenomenon in a particular situation is, useful for understanding similar phenomena in similar situations (Burns \& Grove, 2003:3738; Mouton, 1996:133; Mouton \& Marais, 1990:52). The strategy of this research is contextual in nature (Mouton, 1996:133; Mouton \& Marais, 1990:52). The research thus aims to provide a description and an exploration of a particular phenomenon or experience or group, within the context of the phenomenon's specific setting and world significance.

This research focused on how mothers experienced the loss of a baby during pregnancy and the care given by midwives and doctors in a public hospital in Gauteng. Their viewpoints will be based on knowledge obtained through the field study.

\section{DATA COLLECTION}

In-depth unstructured interviews were conducted with mothers who lost a baby during pregnancy. These interviews were taped and transcribed verbatim in the language preferred by the mother. The interviews were held within the first six weeks after the diagnosis had been made. The time depended on the emotional condition of the mother because immediately after delivery, some mothers were too emotional to discuss or describe their loss. Therefore interviews were scheduled from fortyeight hours to six weeks after delivery for those who were not ready for the interview when they were still in hospital.

One question was asked, namely: "Describe how you experienced the loss of your baby during pregnancy and the care you received from both midwives and doctors during this period". During the interview communication skills were used to obtain the necessary information. 
The researcher contacted each participant to confirm an appointment at a central place and at an appropriate time for the participants. Comments were made about sensitive ethical issues such as maintaining confidentiality of data, preserving the anonymity of the informants and using research for its intend purposes (Creswell, 1994:148). The ethical standards as set by the Democratic Nursing Organisation of South Africa (DENOSA) were adhered to before and during the interview (DENOSA, 1998:1-7).

The researcher created a context that was conducive for mutual trust between the researcher and the participant (Marshall \& Rossman, 1995:67). Privacy was ensured during the interview. The participants were ensured that their participation was entirely voluntarily and they could withdraw from the research at any stage if they felt so. The interviews would be stopped if the participant suffered severe stress during the interview. The possibility of referring the participants for councelling was discussed with them after the interview.

A pilot study was conducted with one mother to refine the question (Burns \& Grove, 2003:38). The question was asked to one mother and the interview was conducted as planned. The reason was to see whether the question was clear to the mother and whether the interview developed as planned. The mother understood the question and the interview went well, so no changes were made to the question and interview procedure. This mother and interview was therefore added to the main sample.

\section{POPULATION AND SAMPLING}

\section{Population}

The population consisted of mothers who lost a baby at any stage during pregnancy and who were admitted to a maternity unit of a public hospital in Gauteng. It is mostly Black patients who are treated in this hospital. The research is bound to the uniqueness of this specific academic public hospital in Gauteng and is not representative of the whole population.

\section{Sampling}

A purposive sampling method was used to select the mothers, using set criteria, that is, all mothers who lost their babies during pregnancy and who were admitted to the maternity unit were interviewed. Patton (in Denzin \& Lincoln, 1994:229) suggests that the logic and power behind purposive selection should be information-rich. In this research the adequacy of the research was attained when sufficient data had been collected so that saturation occurs and variation is both accounted for and understood (Denzin \& Lincoln, 1994:230). Saturation means that themes and categories in the data become repetitive and redundant, such that no new information can be gleaned by further data collection (Polit \& Hungler, 1999:43). Ten mothers were sampled when saturation was achieved.

\section{DATA ANALYSIS}

"The intent of the analysis was to organise the data into a meaningful, individualized interpretation or framework that describes the phenomenon studied" (Burns \& Grove, 2003:29). Tape recordings of the interviews were transcribed verbatim in the language in which the interviews were held. Transcriptions were analysed by the researcher according to Tesch (unmodified) (in Creswell, 1994) and by an independent coder. The person was requested to also analyse the data according to Tesch's method, independently from the researcher. The two analyses were then compared to ensure trustworthiness. She was selected as she has obtained her DCur (Nursing), with a thesis in which she also used qualitative interview methods. Data analysis is a process of bringing order to the data, organising what is collected into concepts, categories and basic descriptive statements (Patton, 1987:144).

\section{Enhancing trustworthiness}

Trustworthiness refers to the extent to which a research study is worth paying attention to, worth taking note of, and the extent to which others are convinced that the findings are to be trusted (Babbie \& Mouton, 2001:276). The criteria by Lincoln and Guba (1985:290-300) served as guidelines for the researcher.

To enhance credibility the researcher:

- had prolonged contact with the study field. She is a midwife, who has knowledge and clinical experience in this area. The literature that was consulted enabled her further to satisfy the criterion of being knowledgeable about the phe- 
nomenon under investigation;

- bracketed existing knowledge and preconceived ideas and especially personal views about the existing problems in the clinical area; and

- conducted the phenomenological semi-structured interviews until data saturation occurred, namely until the collected data were repeated and confirmation of previously collected data took place (Streubert \& Carpenter, 1995:22-23).

The categories identified by the researcher were compared with those identified by the other coder. No major discrepancies were identified between these persons' analysis of the data. An in-depth literature review further confirmed these categories. This enhanced confirmability.

Transferability was ensured by the researcher providing in-depth discussions of the data obtained, data analysis and interpretation of the research findings, in a research report.

\section{RESULTS}

The results were based on the analysis of the in-depth, unstructured interviews with mothers about how they experienced the loss of a baby during pregnancy and the care they received from doctors and midwives. After a discussion with the independent coder all identified themes and sub-categories were finalised. A literature control was integrated as a further measure of trustworthiness of the findings (Lincoln \& Guba, 1985: 294-331).

All mothers who were interviewed described their experiences of the loss of a baby during pregnancy, some shared the same experiences, but some did not. The themes of experiences that were identified were:

Table 1: The experiences of mothers who lost a baby during pregnancy $(\mathrm{N}=10)$

Themes - The mother's experience of the loss
- $\quad$ Confused (losing one's mind)
- $\quad$ Emptiness (there is no fulfillment)
- $\quad$ Pain (emotional pain)
- $\quad$ Anger (towards oneself, baby, nurses and doctors)
- $\quad$ Guilt (that maybe she caused the death)
- $\quad$ Fear (of falling pregnant again)
- $\quad$ Denial (that she lost the baby)
- $\quad$ Failure (to fulfill expectations)
- $\quad$ Frustration (because of losing the baby)
- Loneliness (because of isolation)
- $\quad$ Lost hope (of falling pregnant again)
Themes - The experience of mothers regarding the care given by midwives and
doctors during the incident
- $\quad$ Lack of communication leading to lack of information
- Lack of therapeutic listening
- Lack of emotional support
- Insensitivity
- Health workers do not care about patients




\section{Confusion}

Mothers experiencing the loss of a baby during pregnancy have confused emotions and feel as if they are losing their minds.

The following excerpts from the interviews support this discussion: "I really feel terrible. I feel confused and I feel as if I am going to lose my head". "Finally, I heard my baby crying weakly. Nobody said anything, so I asked, 'Is it a boy or a girl?' My doctor responded that there were problems and she could not tell. I was confused, I must have heard wrong. I asked her again. She repeated the same answer with no other explanation. No one showed me my baby".

Chalmers (2000:16) states that what most people dread after losing a baby is that their experiences may seem to be illogical or irrational. However, when bereaved couples talk with other parents who have lost a baby, it soon becomes clear that "they are not going crazy", but that the up-and-down and "confusion" feelings they are experiencing are common reactions to pain and are to be expected.

Borg and Lasker (1981:17) suggest that parents sometimes think they are "going crazy". Their emotional reaction is so strong that they become disoriented, depressed, bitter and withdrawn for many months and maybe even years. Friends may expect them to bounce back quickly, have another child and try to forget the past, but they cannot forget. Borg and Lasker (1981:36) further suggest that whatever the source of failure of others to express sympathy, it leaves couples feeling alone and confused about their emotions. Many people never speak about a miscarriage at all and have a very difficult time resolving their grief. They may find it hard to tell people who did not even know they were expecting, that the pregnancy had ended. Often, however, they find comfort from talking to others who have themselves been through a miscarriage and who can understand the sadness, the fears, the anger and the disappointment.

\section{Emptiness}

According to mothers who lost a baby during pregnancy, there is no fulfillment of giving birth to a baby because there is no baby. They came back from hospital with empty hands whilst other mothers were holding their babies. "You know, I just felt confused. I could not cry, I really felt empty". "When a child is born dead, there is nothing. The world remembers nothing and the gap in the womb is replaced by an emptiness in your arms. You are not recording a birth or a death".

\section{Sadness}

Mothers who have lost a baby before giving birth, feel sad because of this tragedy, and because of the emptiness and disappointment. "But I am glad that I held him because I know that I was pregnant and it was not just me dreaming. I am glad in that respect, but it's very sad, because I know what he looked like and I know he was gorgeous, and I think it's unfair...".

According to Borg and Lasker (1981:20), there is also an overwhelming sadness as is usual after any tragedy. Some parents feel sad for the baby. They say that it seems particularly unfair for a baby to die. It is expected that an elderly person, who has experienced life, will die, but an infant is thought to deserve a chance at life. They are sad for themselves as well, sad because of the emptiness and disappointment. Their wish to become parents - to have someone to nurture, to love, to teach, to care for, to play with - someone who would care for them in their old age and inherit the benefits of their work - has not been granted.

\section{Pain}

Mothers say the pain they are feeling is not physical pain but emotional pain because in the end there is no reward. The following excerpts confirm this: "At times it is not easy to communicate the pain because there is simply no appropriate language with which to describe the tragedy". "It was painful and when I say painful I don't mean like a headache! But what can I say ... emotional pain".

When a baby is stillborn the hopes built up during the months of pregnancy are suddenly gone. It is not only the mother who is affected. Fathers also develop an attachment to the baby before it is born. Some stillbirths occur with foreknowledge of the situation and it is known that the baby is already dead. This is very painful for parents, especially if they have to wait for the natural onset of labour to produce a dead baby 
(Wright, 1992:102).

\section{Anger}

The anger that these mothers experience is because they have delivered a dead baby. To them there is no reward. Sometimes they are angry with themselves, the baby, the nurses and the doctors. "The anger is because you are going to deliver a foetus that is dead. I'm going to go through this pain and in the end there is no reward. There is no baby. You come home empty. Nothing ... Life goes on". "I needed people to acknowledge what had happened, not to trivialise it. I was grateful for the people who listened, and stayed, knowing that they could not take away the hurt. I was angered by those who tried to make it better, with false comfort and too quickly offered explanations ...".

In the study conducted by Cleirel (1991:256), it was shown that "... anger after loss must be seen as an individually defined way of coping with the loss, rather than a "typical" part of the loss reaction. Feelings of anger are often regarded as protest against the loss. It has been found that it may be directed towards different people, objects or circumstances that may also be held responsible for the death".

Woods and Esposito (1987:138-139) explain that often, behind the question "why?" is anger. This anger has no focus. Parents are angry at everything and everyone at the same time. They realise that no one and nothing can be blamed. How frustrating this is. Sometimes, parents are able to express anger at God. They ask, "Why, when there are so many people out there who mistreat children, does God allow them to have babies, and yet he stops us from having this child we wanted so much?"

Anger is the result of a gradually developing awareness of the reality of the situation. As the significance of their loss of a baby during pregnancy begins to dawn on them, parents (and significant others) experience the different emotions of anxiety and anger. With the full effect of their loss, come more focused feelings of bitterness, resentment, blame, rage, and envy of those with normal pregnancy outcomes. Blame and anger may be a destructive force in relationships with family members, and prevent these relationships from being a source of comfort and support. Venting of angry feel- ings on care providers protects these family relationships for more positive interactions (Mereinstein \& Gardener, 1993:536).

\section{Guilt}

Most mothers experience feelings of guilt, because they think that perhaps they caused the death by doing something wrong and sometimes because they failed the child by not carrying her/him to term. The following excerpts confirm this: "I felt myself it was my fault. I felt it was something wrong with me that makes my babies be born early. I feel it's my body rejecting the baby". "I just don't want to encourage anything to happen. I think really I am blaming myself for going into labour, for getting out of bed. If only I had stayed in bed that extra day, would it have made any difference?"

Most parents (especially mothers) feel guilty that their baby has died. They search the months of pregnancy trying to pin the cause for their child's death on something they may have done. This is a normal reaction, and healthy as long as they talk about it together, rather than hiding these feelings from each other. It is only after they have gone through the long, slow process of checking possible causes that they will gradually come to accept that they did not cause their baby's death (Chalmers, 2000:12).

\section{Fear}

Mothers experience fear falling pregnant again. They fear that loss will happen again. "I still feel sad and I have fear of falling pregnant again".

Meinstein and Gardener (1993:532) mention that, for the family who experiences an intrapartum demise, the joyous expectations of labour and birth suddenly changes to fear, anxiety and dread that the "worst" might possibly happen to them again.

Woods and Esposito (1987:252-253) stress that, if a previous pregnancy has ended disastrously, a couple's anxiety and fears, both founded and unfounded, might be greater than normal. Issues regarding perinatal diagnostic testing need to be discussed. Pertinent information and the rationales in support of or against a patient's having amniocentesis or sonograms performed need to be explored. Many parents, during a subse- 
quent pregnancy, opt for more testing than is probably necessary. The tests eliminate some of their anxiety. Indeed, maternal anxiety is a valid factor to be considered in determining what testing will be done, even if the previous pregnancy would not have had a better outcome if a particular test had been carried out.

\section{Denial}

After losing a pregnancy mothers attempt to deny the reality of the loss, because they do not want to face the pain of this loss.

This is confirmed by the following excerpt: "After the miscarriage was over, I had this crazy feeling that I would go home and continue with the pregnancy. I knew the reality, but somehow I did not believe it".

Borg and Lasker (1981:19) explain that, although it is essential that the bereaved parents express their emotions over time and talk about their loss, some degree of denial is a normal part of grieving. It is a form of protection, a way of not having to face up to the pain. "This did not happen to me" is a common feeling.

\section{Failure}

A mother who loses a baby feels that she has failed to fulfil the expectations of being a woman, a mother. She feels she has failed herself, her husband and most of all her child. "I guess it's important to carry on one way or the other. Think of new changes - focus in on something else. There are a couple of courses that I wanted to do, so I can think about a career change. In some way, I feel like a failure and wonder if my life plans are possible. So I think the main thing will be useful and meaningful". "I feel ... you know, it is something I cannot describe, but I feel like a failure".

It is common for parents especially the mother, to feel that they are a failure as people, and to be afraid of facing people as failures (Borg \& Lasker, 1981:148).

\section{Frustration}

Mothers with the loss of a baby during pregnancy become frustrated because they could not achieve their goal of delivering a live baby.
The following excerpts confirm this: "Although I did not want others to suffer, I was angry, frustrated and depressed, and so I distanced myself". "I felt bad, and frustrated because when you carry the baby for so long, you expect a sort of reward, that is, getting a live baby ... This is really frustrating".

When a tragedy occurs, a woman's confidence is often shattered. The effort of becoming pregnant and planning for a baby is too great, and she is determined never to go through such a trauma again. For the woman who very much wanted a child and can no longer look forward to having one, there is a deep frustration in addition to the grief for the baby who was so loved (Borg \& Lasker, 1981:94).

\section{Loneliness}

Mothers who have lost a baby in pregnancy often feel lonely and empty, and this feeling of loneliness inexplicable. "I though I was going crazy and ah, I hoped for it, so the pain would stop. Because it just hurt so much - the loneliness ... just unbelievable loneliness. Ah, it's just like - the pain and the loneliness and having to deal with it, ah! You just kind of wish you would slip over that edge into some unknown space and not have to worry about it any more".

Borg and Lasker (1981:7-8) report that bereaved parents experience feelings of being alone and isolated from others. Most of their family and friends do not understand what sort of emotional support is needed. "At least you never knew this child", they will say, hoping to ease the pain or "it could have been worse" or "you'll have another one". In their own way, they might be trying to offer hope for the future, but to the bereaved parents, it often seems that these people do not comprehend the enormity of what has happened.

\section{Lost hope}

Mothers lose hope because all their hopes and dreams were lost through this tragedy. There is profound disappointment and all plans collapse. "I felt empty because I knew I was going to give birth to a dead baby, and I lost hope".

One participant in Pilkington's study (1993:134) said she was feeling empty with shattered dreams and lost 
hope. The participant reached out to God for strength and found an acceptance and a desire to pull through one step at a time, while weighing her blessings and finding ways to fill hollow feelings.

\section{FEEDBACK FROM THE MOTHERS WITH THE LOSS OF A BABY DURING PREG- NANCY ON THE CARE GIVEN BY MID- WIVES AND DOCTORS}

\section{Lack of communication that leads to lack of information}

Mothers raised concerns about midwives and doctors not communicating with them. Therefore, it would appear that these mothers are not given enough information, sometimes none at all. This in itself will lead to them making uninformed decisions. "Even in the antenatal ward, nurses don't communicate with you". "Doctors don't have time for the patients. Just a few. But they don't have time for the patients! Most of them don't have time for the patients. So, I thought maybe that once they talked to the nurse about the patient's problem or when they write in the bedletter, that means they leave it to the nurses".

\section{Lack of therapeutic listening}

Mothers stated that they wished that midwives and doctors could give them a listening ear when they spoke about their loss. They mentioned how frustrated they were, because most of the time there was nobody to talk to and the stress built up.

The following excerpt confirms this: "Because most of the time at home there is no time for this, when you arrive at the hospital, you find women with their kids, happy, and you are sitting there with a painful heart, in tears. You miss a person who will sit next to you, and let you open up to her".

According to Mander (1999:1) if possible a sympathetic listening ear is needed, but in the absence of a human ear other means such as pen and paper, may allow the necessary outpouring to help her to make connections between this experience and the other strands of her life.

\section{Lack of emotional support}

What mothers would like to see is midwives and doctors giving them emotional support by comforting, talking and being there during this time.

The following excerpt confirms this: "What I ask from the nurses is that they should try hard to comfort patients who come in. They should try hard to look at the other person's problem, try to comfort her the way they have been taught, and according to their capability, because most of the time, at home there is no time for this".

Mereinstein and Gardener (1993:545-546) explain that professional presence and support are essential to families in crisis because of the increased dependency needs that accompany grief and loss. Yet certain aspects of the environment such as privacy, quiet and comfort may be difficult to obtain in a noisy and busy perinatal setting. The recommendation to never leave the family alone must be balanced with their need for privacy and personal time alone with their baby (that is, stillborn, ill or dying). Simply saying, "I will stay with you unless you ask me to leave so that you can have some private time with your child" or "Would you like me to leave for a while so that you can be alone with your baby?" offers both support and privacy.

\section{Insensitivity}

Most of the time midwives and doctors are insensitive in the way they treat mothers and their stillborn babies. These mothers are screened in the labour ward and they deliver without any person attending to them. Dead babies are not treated the same as those who are alive, and they are often wrapped in plastic or placed in a receiver. "I wanted to be treated like others, but because he was dead, I could just deliver him on a plastic".

Woods and Esposito (1987:65-66) suggest that, at delivery, care providers should balance the patients' perception of events with technical aspects of the procedure. All too often, stillborn foetuses are delivered into a pan or in the labour bed. Although these approaches may satisfy clinical standards for a stillbirth delivery, they can impart a very negative and uncaring attitude to the patient. 


\section{Health workers do not care about patients}

Mothers experienced a lack of care for them as patients. It appeared to many of the mothers that, once their doctors established that the baby was dead, they relinquished care to the nurses.

The following excerpts confirm the discussion: "Doctors don't have time for the patients. Just a few. But they don't have time for the patients! Most of them don't have time for the patients. So, I thought maybe that once they talked to the nurse about the patient's problem or when they write in the bed letter that means they leave it to the nurses". "The doctor avoided me, and when I pressured him, he said: 'These things happen and you should try to put that behind you'. He really offered no support, he was so cold".

\section{LIMITATIONS}

One limitation was that the researcher did not always gain the co-operation of the staff in the clinical area. As they failed to call the researcher when there was a mother to be interviewed, some clients would leave without being seen by the researcher.

\section{RECOMMENDATIONS}

The results from the interviews held with mothers with the loss of a baby during pregnancy elicited many personal emotional experiences. In addition, there was some dissatisfaction with the care received from midwives and doctors. Recommendations to address this are the following:

\section{Nursing research}

It will be advisable to conduct research with the health workers, where they are given the opportunity to describe their experiences when caring for these women and thus share their own views. Further research can be conducted in other institutions, to see if the same results are found.

\section{Nursing practice}

It is important to advocate for hospital policy that includes providing support for staff members, as they are emotionally affected by working with bereaved families.
Better support for staff would help them to provide better support for parents. Nursing guidelines should be developed for quality care of these patients.

\section{Nursing education}

There is a need to educate nurses on the grieving process and specific interventions for bereavement care.

\section{CONCLUSION}

In the findings of this research, it became clear that mothers with the loss of a baby during pregnancy experienced hardships and difficult times during this time. They wished that people acknowledged their loss, were considerate, sensitive and gave them a listening ear and emotional support. On the other hand mothers reflected the inability of health workers in giving them the appropriate support. The health care providers should keep in mind that every parent in this situation is on their own journey. Their job is to walk with the parents on their journey.

\section{LIST OF REFERENCES}

BABBIE, E \& MOUTON, J 2001: The practice of social research. Cape Town: Oxford University Press.

BAKER, L \& NACKERUD, L 1999: The relationship of attachment theory and perinatal loss. Death Studies, 23(3):1.

BORG, S \& LASKER, J 1981: When pregnancy fails. Boston: Beacon Press.

BURNS, N \& GROVE, SK 2003: The practice of nursing research: Conduct, critique and utilization. Toronto: WB Saunders.

CHALMERS, C 2000: A cross-cultural survey of women's experiences. Journal of Nurse-Midwifery, 39(4):265-272.

CLEIREL, MPH 1991: Adaptation after bereavement. A comparative study of the aftermath of death from suicide, traffic accident and illness of the next of kin. Proefschrift. Amsterdam: Rijks Universiteit.

CONDON, JT 1986: Management of established pathological grief reaction after stillbirth. American Journal of Psychiatry, 143:987-992

CRESWELL, J 1994: Research design. Qualitative and quantitative approaches. London: Sage.

DEMOCRATIC NURSING ORGANISATION OF SOUTHAFRICA 1998: Ethical standards for nurse researchers. Pretoria: DENOSA.

DENZIN, NK \& LINCOLN, YS 1994: Handbook of qualitative research. Thousand Oaks: Sage.

FRAZER, DM \& COOPER, MA 2003: Myles textbook for midwives; 
$14^{\text {th }}$ edition. London: Churchill Livingstone.

KENNEL, JH \& KLAUS, MH 1984: Parent-infant bonding; $2^{\text {nd }}$ edition.

London: CV Mosby.

LINCOLN, YS \& GUBA, EG 1985: Naturalistic inquiry. Beverly Hills:

Sage.

MANDER, R 1999: Miscarriage - The loss of a baby. AIMS Journal, 10(4):1

MARSHALL, CE \& ROSSMAN, GB 1995: Designing qualitative research. Newbury Park: Sage.

MERENSTEIN, GB \& GARDENER, SL 1993: Handbook of Neonatal Intensive Care; $3^{\text {rd }}$ edition. St Louis: CV Mosby.

MOUTON, J \& MARAIS, JC 1990: Methodology of the social sciences: Basic concepts. Pretoria: Human Research Council.

MOUTON, J 1996: Understanding social research. Pretoria: JL van Schaiks.

PATTON, F 1987: Qualitative evaluation and research methods. Newbury Park: Sage.

PILKINGTON, FB 1993: The lived experience of grieving the loss of an important other. Nursing Science Quarterly, 6(3):130139.

POLIT, FD \& HUNGLER, BP 1999: Nursing research, principles and methods; $6^{\text {th }}$ edition. Philadelphia: JB Lippincott.

STRUEBERT, HJ \& CARPENTER, DR 1995: Qualitative research in nursing: Advancing the humanistic imperative. Philadelphia: JB Lippincott.

WOODS, JR \& ESPOSITO, JL 1987: Pregnancy loss: Medical therapeutics and practical considerations. Baltimore: William \& Walkins. WRIGHT, B 1992: Skills for caring, loss and grief. London: Churchill Livingston. 